Original Contribution

\title{
GENDER, WATER QUALITY AND CATFISH PRODUCTION FOR LIVELIHOOD SUPPORT: EVIDENCE FROM CATFISH FARMERS IN LAGOS STATE, NIGERIA
}

\author{
O. Oyinbo*, M. O. Mohammed
}

\author{
Department of Agricultural Economics and Rural Sociology, Ahmadu Bello University, Zaria, Nigeria
}

\begin{abstract}
This research was undertaken to examine the gender perspective of Catfish farming as a livelihood base and the issue of water quality using a case study of Lagos state, Nigeria. Primary data elicited from a sample size of 70 Catfish farmers (38 male and 32 female Catfish farmers) were employed in the data. Analysis of the data was done using descriptive statistics, gross margin analysis and $\mathrm{Z}$ statistic. The result of the data analysis revealed that the profitability of the male Catfish farmers was higher than that of the female Catfish famers and this implies that women with a lower profitability compared to men will tend to have a lower livelihood support from Catfish production in contrast to men who will tend to have a higher livelihood support from Catfish farming as a result of their higher profit margin. All the women catfish farmers attributed poor water quality to be the major constraints militating against their profitability in Catfish farming and invariably their source of livelihood. It is recommended that mainstreaming gender in manpower training, equitable distribution of resources and access to supportive services should be prioritized towards enhancing their Catfish productivity and improving their livelihood support.
\end{abstract}

Key words: Aquaculture, Female, Gross margin, Profitability, Male.

\section{INTRODUCTION}

Fisheries occupy a unique position in the agricultural sector of the Nigerian economy. The contribution of the fisheries sub-sector to agriculture GDP was estimated as $1.3 \%$ in the year 2010, out of the total estimate of $40.9 \%$ being contributed by agriculture to GDP (1). Although fish production is traditionally considered as masculine enterprise, women's role in fisheries is complementary and crucial (2). Women play a major role in aquaculture production around the world as labourers and managers of the production process; their roles are very much restricted and often ignored. The gender roles of women in aquaculture production are recognized in three ways or stages of production: fishing, processing and marketing. Gender is a concept used in social science analysis to look at roles and activities of men and women. The focus of gender analysis is not on

*Correspondence to: $O$. OYINBO, Department of Agricultural Economics and Rural Sociology, Ahmadu Bello University, Zaria, Nigeria. P.M.B. 1044, Email: ooyinbo@abu.edu.ng

222

Trakia Journal of Sciences, Vol. 13, № 3, 2015 biological differences between men and women but rather on their experiences as members of society. It is often assumed that men are farmers while women are farmers' wives and helpers. This has been the case in many international and national agricultural development policies and programs in the past. In some cases, such assumptions have led to the failure of targeting programs effectively or achieving program objectives.

Fish farming is the least exploited fishery subsector with the vast brackish water fishing grounds almost unexploited (3). Less than 1.0 per cent of the fresh water grounds and about 0.05 per cent of the brackish water grounds are under aquaculture to produce a current average yield of 20,500 tonnes of fish per annum. Despite the increase of fish production in Nigeria, production level is still very low and this has been attributed to high cost of input, lack of credit to fish farmers at low interest rate, lack of skilled manpower and an ineffective aquaculture extension service system(4). This represents only 3.12 per cent of the estimated 
fish culture potential of 656,815 tonnes per annum. Nigeria spends $\$ 100$ billion on fish importation annually and the current fish demand consumption in Nigeria stands at over 2.66 million tonnes per annum, while the present importation rate is over 750,000 metric tonnes (4).With importation of more than 750,000 MT of fish, more than USD 600 million are spent in hard currency and thousands of jobs are exported (5). The continuous importation of fish portends a colossal loss of foreign exchange earnings to Nigeria (6).

The most popular fish species that have proved desirable for culture in Nigeria are the Clariid fishers; Clarias gariepinus, Heteroclarias sp. and Heterobranchus species (7). Other species that are commonly cultured are the Tilapias (Oreochromis niloticus, Sarotherodon galilaeus and Tilapia guinensis). Heterotis niloticus, Gymnarchus niloticus, Mugil cephalus and Chrysichthys nigrodigitatus. These species are adaptable to different patterns under various natural and socio-economic conditions. In Lagos State, the importance of $C$. gariepinus has no less than elsewhere in Nigeria based mainly in the farmers' and consumers' preferences (7).

Although several Studies $(8 ; 9 ; 10)$ on Catfish farming have been carried out in Nigeria but without any recluse to the issue of gender, water quality and livelihood support. Therefore, this study was designed to bridge the knowledge gap by providing empirical information on gender perspective of Catfish farming as a means of livelihood and the issue of water quality in Catfish farming using Alimosho Local Government Area of Lagos State of Nigeria as a case study.

\section{HYPOTHESIS}

Null hypothesis $\left(\mathrm{H}_{\mathrm{o}}\right)$ : There is no significant difference between the profitability of Catfish fish production of male and female Catfish farmers.

Alternate hypothesis $\left(\mathrm{H}_{\mathrm{a}}\right)$ : There is no significant difference between the profitability of Catfish fish production of male and female Catfish farmers.

\section{METHODOLOGY}

\section{DESCRIPTION OF THE STUDY AREA}

The study area is Alimosho Local Government Area in the North-western part of Lagos State. It is located at latitude $6.61056^{\circ} \mathrm{N}$ and longitude $3.29583^{\circ} \mathrm{E}$ with a temperature range of $28^{\circ} \mathrm{C}$ to
$33^{0} \mathrm{C}$. It occupies a land area of $173.6 \mathrm{sq} \cdot \mathrm{km}$ (67sq. miles). It is the largest Local Government Area in Lagos state with 1,277,714 inhabitants according to the official 2006 Census. It is estimated that the population will increase to 1,592,911 at the end of 2013 based on an annual population growth rate of $3.2 \%$. The state has vast water resources for fish farming activities.

\section{SAMPLING PROCEDURE AND SAMPLE SIZE}

A two stage sampling technique was used in the study. The first stage involved a purposive selection of wards M1, G North, G South, H, D, $\mathrm{F}$, and ward $\mathrm{E} 1$ out of the eleven wards in the Local Government Area. The purposive selection of these wards is based on their peculiarity in Catfish farming in the study area. The second stage involved a random selection of 10 fish farmers from each of the 7 selected wards to give a sample size of 70 Catfish farmers(38 male and 32 female Catfish farmers) which represents $50 \%$ of the sample frame $(140$ Catfish farmers) of Catfish farmers in the study area.

\section{METHOD OF DATA COLLECTION}

Primary data were used in this study. The primary data were obtained from the respondents using a well structured questionnaire with the aid of personal interview during the field survey. The primary data collected include; administrative information, the socio-economic characteristics of Catfish farmers in the study area, inputs used for catfish production per annum, the output of Catfish production per annum and the constraints militating against the profitability of fish production in the study area.

\section{ANALYTICAL TECHNIQUES}

Analysis of the data was done using descriptive statistic, gross margin analysis and $\mathrm{Z}$ statistic. Descriptive statistics such as mean, percentage and frequency distribution was employed to describe the socioeconomic characteristics of the male and female Catfish farmers. The gross margin analysis was employed to determine the profitability of Catfish production from a gender perspective. The gross margin was calculated as the difference between the gross farm income and the total variable cost (12). Mathematically it is expressed as:

$\mathrm{GM}=\mathrm{GI}-\mathrm{TVC}$

$\mathrm{GM}=$ Gross margin $\quad \$ / \mathrm{m}^{2}$ of pond per

production cycle

$\mathrm{GI}=$ Gross farm income $\quad \# / \mathrm{m}^{2} \quad$ of pond

per production cycle 
TVC = Total variable cost $\quad \# / \mathrm{m}^{2} \quad$ of pond per production cycle

i. The Z-statistic: this was used to test the hypothesis of the study. It is expressed as follows:

$\mathbf{Z}=\sqrt{\frac{\mu_{1}-\mu_{2}-\Delta}{\frac{\sigma_{1}^{2}}{\mathrm{n}_{1}}+\frac{\sigma_{2}^{2}}{\mathrm{n}_{2}}}}$

Where $\mathrm{Z}=$ calculated $\mathrm{Z}$ value

$\mu_{1}=$ Mean profitability of the male Catfish farmers.

$\mu_{2}=$ Mean profitability of the female Catfish farmers.

$\sigma_{1}=$ Standard deviation of the male Catfish farmers.

$\sigma_{2}=$ Standard deviation of the female Catfish farmers.

$\mathrm{n}_{1}=$ Sample size of the male Catfish farmers

$\mathrm{n}_{2}=$ Sample size of the female Catfish farmers

$\Delta=$ Hypothesized mean difference

\section{RESULTS AND DISCUSSION SOCIOECONOMIC CHARACTERISTICS OF MALE AND FEMALE CAT FISH FARMERS}

OYINBO O., et al.

The distribution of the socioeconomic characteristics of male and female Catfish farmers is presented in Table 1. The result shows that majority of the male $(52.6 \%)$ and the female $(53.1 \%)$ Catfish farmers had secondary educational qualification. A larger proportion $(50 \%)$ of the male Catfish farmers had 5-9 ponds while the larger proportion of the female Catfish farmers had $1-4$ ponds. This implies that the male Catfish farmers had access to more ponds that could enhance their production and livelihood. Most of the male and female Catfish farmers had no access to training on Catfish production. However, the male Catfish farmers had more access to training than the female cat fish farmers as indicated by $10.5 \%$ of the male Catfish farmers and $3.1 \%$ of the female Catfish farmers respectively. This implies that there is the need for institutional support to in the area of training to Catfish farmers especially the women so as to enhance their productivity in Catfish production. This is in line with (13) who noted that to ensure that women utilize their full potentials in profitable activities, like aquaculture, it is necessary to provide capacity building support to rural women.

Table 1. Distribution of the socioeconomic characteristics of male and female Catfish farmers

\begin{tabular}{lrrrr}
\hline & Mreq & Male & Freq & \%emale \\
\hline Formal Education & & & & \\
Primary & 1.0 & 2.6 & 17.0 & 0.0 \\
Secondary & 20.0 & 52.6 & 15.0 & 53.1 \\
Tertiary & 17.0 & 44.7 & & 46.9 \\
Number of ponds owned & & & 17.0 & 53.1 \\
$1-4$ & 16.0 & 41.1 & 10.0 & 31.3 \\
$5-9$ & 19.0 & 50.0 & 4.0 & 12.5 \\
$10-14$ & 2.0 & 5.3 & 1.0 & 3.1 \\
15-19 & 1.0 & 2.6 & & \\
Level of management & & & 25.0 & 78.1 \\
Intensive & 34.0 & 89.5 & 6.0 & 18.8 \\
Semi intensive & 3.0 & 7.9 & 1.0 & 3.1 \\
Extensive & 1.0 & 2.6 & & \\
Access to training & & & 31.0 & 96.9 \\
No & 34.0 & 89.5 & 1.0 & 3.1 \\
Yes & 4.0 & 10.5 & & \\
Access to credit & & & 16.0 & 50.0 \\
Yes & 15.0 & 39.5 & 16.0 & 50.0 \\
No & 23.0 & 60.6 & & \\
& & & & \\
\hline
\end{tabular}




\section{GENDER BASED PROFITABILITY ANALYSIS}

The result of the profitability of Catfish production from a gender perspective is reported in Table 2. The gross margin analysis for the calculation of the profitability was carried out on per square metre of fish pond per production cycle. The result shows that the total variable cost incurred by male and female farmers were 6, 170 and 5, 161 naira respectively while the total revenue accrued to the male and female farmers were 14, 252 and 11, 482 naira respectively. The gross margin of the male Catfish farmers (8, 082 naira) was higher than that of the female Catfish farmers (6,321 naira) which indicates that the profitability of the male Catfish farmers was higher than that of the female Catfish famers. The returns per naira of 2.31 for the male Catfish farmers implies that for every 1 naira invested in Catfish production, the farmers make a return to investment of 2.31 naira. In the case of the female Catfish farmers, a return per naira invested was estimated to be 2.22 naira which indicates that for every 1 naira invested in Catfish production, the farmers make a return to investment of 2.22 naira. Although, the male and female Catfish farmers make profit from investment in Catfish farming, the profit margin of the male Catfish farmers was higher
OYINBO O., et al.

than that of the female Catfish farmers. A plausible explanation for the observed difference in the profit margin of the male and female Catfish farmers is that access to resources especially quality water for fish production, control of assets, decision-making powers between women and men tend to favour the male Catfish farmers than the female cat fish farmers.

This is in line with (14) who noted that women have more difficult access to water in Lagos state. (15) who opined that gender affects access to labor, land and other important inputs for production and may also affect preferences around production processes and outputs. Also, (16) noted that within the household, women may also have less tenure security than men, which makes them less likely to invest in certain types of agricultural technologies that can enhance their productivity. (17) also noted that women have limited access to land and starting capital for agriculture. The implication of the result of the gender based profitability analysis is that women with a lower profitability compared to men will tend to have a lower livelihood support from Catfish production in contrast to men who will tend to have a higher livelihood support from Catfish farming as a result of their higher profit margin.

Table 2. Average costs and returns of cat fish production per square metre of fish pond

\begin{tabular}{|c|c|c|c|c|}
\hline \multirow[b]{2}{*}{ Item } & \multicolumn{2}{|c|}{ Male cat fish farmers } & \multicolumn{2}{|c|}{ Female cat fish farmers } \\
\hline & Amount & $\%$ of cost & Amount & $\%$ of cost \\
\hline \multicolumn{5}{|l|}{ Variable cost } \\
\hline Cost of fingerling & 1,691 & 27.41 & 1,398 & \\
\hline 27.09 & & & & \\
\hline Cost of labour & 583 & 9.45 & 496 & 9.61 \\
\hline Cost of feeds & 3,896 & 63.14 & 3,266 & 63.28 \\
\hline Total variable cost(TV) & 6,170 & & 5,161 & \\
\hline \multicolumn{5}{|l|}{ Revenue } \\
\hline Output(Kg) & 121 & & 92 & \\
\hline Total revenue(TR) & 14,252 & & 11,482 & \\
\hline Gross Margin(TR - TVC) & 8,082 & & 6,321 & \\
\hline Returns per naira invested & 2.31 & & 2.22 & \\
\hline
\end{tabular}

NB: 158 Naira $=1$ dollar at the time of data analysis

\section{TEST OF HYPOTHESIS}

The null hypothesis which states that there is no significant difference in profitability between male and female Catfish farmers in the study area was rejected because the calculated $\mathrm{z}$ value
(76.2) is greater than the $\mathrm{z}$ critical one tail (1.64) and two tail (1.96) at $1 \%$ level of profitability as shown in Table 3. We then conclude that there is a significant difference in the profitability between male and female Catfish farmers in the study area. 
Table 3. z-Test: Two Sample for Means

\begin{tabular}{llc}
\hline & Male cat fish farmers & Female cat fish farmers \\
\hline Mean & 8080.157895 & 6321.5625 \\
Known Variance & 8657.802 & 9744.62 \\
Observations & 38 & 32 \\
Hypothesized Mean & 0 & \\
Difference & & \\
z & 76.21926297 & \\
$\mathrm{P}(\mathrm{Z}<=\mathrm{z})$ one-tail & 0 & \\
$\mathrm{z}$ Critical one-tail & 1.644853627 & \\
$\mathrm{P}(\mathrm{Z}<=\mathrm{z})$ two-tail & 0 & \\
$\mathrm{z}$ Critical two-tail & 1.959963985 & \\
\hline
\end{tabular}

CHALLENGE OF POOR WATER proper disposal of water from ponds as indicated QUALITY AND OTHER CONSTRAINTS by 30 out of the 32 women Catfish farmers is a AFFECTING THE PROFITABILITY OF high ranking constraint affecting the income CAT FISH FARMING generation from Catfish farming. The major The result in Table 4 shows that all the women Catfish farmers attributed poor water quality to be the major constraints militating against their profitability in Catfish farming and invariably their source of livelihood. Also, the issue of issue that is militating against the profitability of men Catfish farmers is high cost of feeds as indicated by 28 out of the 38 men Catfish farmers.

Table 4. Poor water quality and other constraints affecting the profitability of cat fish farming

\begin{tabular}{lcccc}
\hline & \multicolumn{2}{c}{ Male } & \multicolumn{2}{c}{ Female } \\
& Freq & \% & Freq & \% \\
\hline a. Poor water quality & 15 & 46.9 & 32 & 100.0 \\
b. High cost of feeds & 28 & 73.7 & 22 & 68.8 \\
c. Water disposal & 17 & 44.7 & 30 & 93.8 \\
d. Inadequate funds & 20 & 52.6 & 12 & 37.5 \\
e. Lack of extension services & 30 & 78.9 & 26 & 81.3 \\
f. Pest and diseases & 16 & 42.1 & 25 & 78.1 \\
g. High cost of labor & 9 & 26.7 & 8 & 25.0 \\
h. High cost of pond maintenance & 12 & 31.6 & 24 & 75.0 \\
i. High mortality of fish & 10 & 26.3 & 22 & 68.8 \\
j. Shortage of fingerling & 19 & 50.0 & 18 & 56.3
\end{tabular}

NB: Multiple responses was allowed

\section{CONCLUSION AND RECOMMENDATION}

This study has established that gross margin of the male Catfish farmers( 8,082 naira) was higher than that of the female Catfish farmers $(6,321$ naira) which indicates that the profitability of the male Catfish farmers was higher than that of the female Catfish famers. Hence, women with a lower profitability compared to men will tend to have a lower livelihood support from Catfish production in contrast to men who will tend to have a higher livelihood support from Catfish farming as a result of their higher profit margin. All the women Catfish farmers attributed poor water quality to be the major constraints militating against their profitability in Catfish farming and invariably their source of livelihood. It is recommended that differences in conditions, needs, access to resources, control of assets, decision-making powers between women and men based on their assigned gender roles are taken into consideration in manpower training, equitable distribution of resources and access to supportive services by both genders towards enhancing their Catfish productivity and increasing their livelihood support. 


\section{REFERENCES}

1. Central Bank of Nigeria, Annual Report for the Year Ended 31st December 2011. Available at: http://www.cbn.org.ng. [Accessed 17 August 2012], 2011.

2. Odulate D. O., George F. O. A. and Idowu, A. A. Role of Women in Fisheries in Coastal Wetland Areas of Ogun State, Southwest Nigeria. Proceedings of the Environmental Management Conference, Federal University of Agriculture, Abeokuta, Nigeria, 2011. pp. $1-9,2011$.

3. Ejiola M.T, and Yinka, O.F. Comparative cost structure and yield performance analysis of upland and mangrove Fish farms in Southwest, Nigeria. International Journal of Agricultural Management and Development, 2(3): 187-198, 2012.

4. Oota, L. Is Nigeria Committed to Fish Production. Accessed online 20th October 2012 from http://blueprintng.com/2012/07/isnigeria-committed-to-fish-production/, 2012.

5. United States Agency for International Development (USAID), Best management practices for Fish farmers in Nigeria. USAID Markets Programme - Nigeria. pp. $1-38$, 2010.

6. Tijani, B. Federal Ministry of Agriculture and Rural Development Action Plan Towards the Attainment of a Sustainable Agricultural Transformation in Nigeria. Being a Lead Paper Delivered at the World Food Day Seminar, Agricultural Show Ground Keffi Road, Abuja, Nigeria. pp. 1 - 10, 2011.

7. Adekoya, B.B., T.O. Ayansawo, A.A. Idowu, O.A. Kudoro and A.A. Salisu. In Directory of fish hatcheries in Ogun state" Ogun state Agricultural Development Programme (OGADEP), Abeokuta, 18 pp, 2006

8. Adewuyi S. A., Phillip, B. B., Ayinde, I. A. and Akerele, D. Analysis of Profitability of
OYINBO O., et al.

Fish Farming in Ogun State, Nigeria. Journal of Human Ecology, 31(3): 179 -184, 2010.

9. Akinrotimi O.A.; Abu., O.M.G., Ibemere, I.F. and Opara, C.A. Economic viability and marketing strategies of periwinkle Tympanotonus fuscatus in Rivers State, Nigeria. International Journal of Tropical Agriculture and Food systems, 3(3): 238 244, 2009.

10. Nwiro E. Fish farming a lucrative business. http://www.thisdaylive.com/articles/fishfarming-a-lucrative-

business/119253/(Accessed online 20th October 2012), 2012.

12. Olukosi J. O. and Erhabor, P.O. Introduction to farm management economics. Agtab publishers limited, Zaria. 1998

13. Nwabueze, G. The Role of Women In Sustainable Aquacultural Development In Delta State. Journal of Sustainable Development in Africa, 12(4): 284 - 293, 2010.

14. Anosike, V. and Fasona, M. Gender dimensions of urban commercial farming in Lagos, Nigeria. Urban agriculture magazine, 12: $27-28,2004$.

15. Doss, C. Designing agricultural technology for African Women Farmers: Lessons from 25 Years of experience. World Development, 29(12):2075-2092, 2001.

16. Goldstein, M. and Udry, C. The profits of power: Land rights and agricultural investment in Ghana. Journal of Political Economy, 116(6):981-1022, 2008.

17. Drechsel, P., Hope, L. and Coe, O. Gender Mainstreaming: Who Wins? Gender and Irrigated Urban Vegetable Production in West Africa. The journal of gender and water, 2(1): 15 - 17, 2013. 